Trinity College

Trinity College Digital Repository

Faculty Scholarship

1998

A New Essenism: Heinrich Graetz and Mysticism

Jonathan Elukin

Trinity College, Jonathan.Elukin@trincoll.edu

Follow this and additional works at: https://digitalrepository.trincoll.edu/facpub

Part of the History Commons 


\section{A New Essenism: Heinrich Graetz and Mysticism}

\section{Jonathan M. Elukin}

Since the Reformation, European Christians have sought to understand the origins of Christianity by studying the world of Second Temple Judaism. These efforts created a fund of scholarly knowledge of ancient Judaism, but they labored under deep-seated pre judices about the nature of Judaism. When Jewish scholars in nineteenth-century Europe, primarily in Germany, came to study their own history as part of the Wissenschaft des Judentums movement, they too looked to the ancient Jewish past as a crucia l element in understanding Jewish history.

A central figure in the Wissenschaft movement was Heinrich Graetz (1817-1891). ${ }^{1}$ In his massive history of the Jews, the dominant synthesis of Jewish history until well into the twentieth century, Graetz constructed a narrative of Jewish history that imbedded mysticism deep within the Jewish past, finding its origins in the first-cen tury sectarian

Essenes. $\stackrel{2}{=}$ Anchoring mysticism among the Essenes was crucial for Graetz's larger narrative of the history of Judaism, which he saw as a continuing struggle between the corrosive effects of mysticism [End Page 135] and the rational rabbinic tradition. An unchanging mysticism was a mirror image of the unchanging monotheistic essence of normative Judaism that dominated Graetz's understanding of Jewish history. Ironically, this narrative model of the history of mystic ism may have been influenced by Christian attacks on Judaism itself, a point which I can briefly take up at the conclusion of the article. First let us turn to the role that the Essenes played in Graetz's historical ideology of mysticism.

Graetz inherited a long intellectual tradition about the identity of first-century sectarians. Ever since the fourth-century historian Eusebius asserted that the therapeutae, a group mentioned by Philo, were actually Christian monks, the religious identity of these Alexandrian sectarians--distinct from the Essenes--had been the subject of constant debate. ${ }^{3}$ Were they Jews or Christian ascetics? During the Middle Ages the tradition articulated by Eusebius gave the Church an additional claim for the antiquity of one of its central institutions. The religious identity of the Essenes, a seemingly similar sectar ian group mentioned by Josephus and other ancient historians, also became a point of dispute. ${ }^{4}$ The secluded, monastic life of the Essenes made them equally likely candidates to be proto-Christians. The dispute over the alleged Christian nature of the therapeutae and the 
Essenes would survive, after generations of Catholic and Protestant sch olarly polemic, into nineteenth-century scholarship on late antique Judaism. $\underline{5}$

It was in the work of Graetz that the Essenes and their putative relationship to Christianity received the fullest treatment by a Jewish historian. ${ }^{6}$ Since the only documented therapeutae were in Alexandria, they could not be considered [End Page 136] likely sources--even if they were Jewish--for a nascent Palestinian Christianity. The Essenes offered more fertile ground to explore the relationship between Judaism and early Christianity.

Graetz's argument that Jesus and Christianity had their origins among the Essenes developed in the context of a fierce scholarly polemic between Christians and Jews in the nineteenth century as well as in the context of internal Jewish debates. Before exp loring this larger background, let us first see how Graetz made his case for the connection between Jesus and the Essenes. Making this connection was crucial for Graetz if Christianity was to be understood as the first systematic expression of a mysticism that had flourished among the Essenes.

The Essenes were the first, according to Graetz, to articulate a firmly held belief in the coming of the Messiah, a belief which had grown in intensity during the turmoil and oppression of Roman rule. ${ }^{7}$ Christianity, "or rather this Essenism intermingled with foreign elements," had its origins in this messianic longing. ${ }^{8}$ It was no surprise that John the Baptist was the first to proclaim the arrival of the Messiah, since he was so obviously an Essene. ${ }^{9}$ Graetz makes his case for John's Essene background on the apparent similarity of their habits, most notably the common theme of daily immersion and the fact that both John the Baptist ("oder richtiger der Essäer" ["or rather the Essene"]) and the Es senes were associated with desert refuges near the Dead Sea. $\underline{10}$

In the same way Graetz accepted received wisdom about the Galilee, which he then used to link Jesus to the Essenes. The Galileans, whence Jesus came, were supposed to be unschooled in the law but fanatical moralists, reminding Graetz of the emphasis on mo rality in Essene circles and in the evangelical accounts of Jesus. 11 There was also an undercurrent of superstition that ran through Galilean society providing another resonance between Jesus and the Essenes, who were known for their obsession with the names of God, angels, and magical practices. $\stackrel{12}{~}$ There was thus a common culture that drew Jesus to the Essenes and made the people of Galilee receptive to his Essene teachings. Indeed, this culture of magic and miracles would make it easier for Graetz to [End Page 137] see the Essenes as proto-mystics. Graetz described Jesus as teaching his disciples Essene principles concerning chastity, suffering, humility, self-denial, as well as other ideals. $\underline{13}$ Even Jesus's brother was thought to be an Essene, and Graetz, in the French translation of his third volume, happily cited Eusebius's Ecclesiastical History to support this point. $\underline{14}$

Graetz does at times recognize the weakness of the evidence, but he pushes ahead in order to establish the Essene background of Jesus. He thus admits that while he cannot prove that Jesus was formally admitted into the order of the Essenes, Graetz asserts that one can only understand Jesus' life and work if it is acknowledged that he adopted Essene principles 
("essäische Grundsätze"). $\stackrel{15}{\underline{15}}$ The early Christians themselves were also really Essenes, or at least were deeply influenced by them. They had simply changed their name to Nazarenes from the original Essenes. $\frac{16}{}$ The early Christians imitated the Essene way of life and took up beliefs in asceticism, demons, and exorcism that had only been marginal to pharisaic Judaism. $\underline{17}$

When Graetz concluded that Jesus and the early Christians had their origins in the Essene communities--and that the milieu was congenial to the development of mysticism--he was not saying something radically new. $\frac{18}{}$ The French-Jewish scholar Joseph Salvador, in Jésus-Christ et sa doctrine (1838), had already asserted that Jesus was influenced by Essene doctrines "pleines de mysticisme" and by the ascetic habits of the Essenes. ${ }^{19}$ Graetz no doubt drew on the long and continuing scholarly tradition that asserted an Essene connection to Christianity. ${ }^{20}$ The link between Christianity and Essenism was so attractive that a forged account of Jesus's life as an Essene monk was published in the early nineteenth century. This work, the Crucifixion of Jesus, by an Eye-witness, [End Page 138] was actually drawn from Venturini's Ur-text on the Essene identity of Jesus, Naturliche

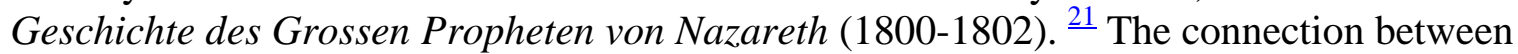
Christ and the Essenes was a true intellectual fad. For example, George Eliot reports in a letter (21 January 1852) to her friend Sara Hennel that a French visitor to her salon was full of the idea: "He dilated on his views of the origin of Christianity--Strauss deficient because he has not shewn the identity of the teaching of Jesus with that of the Essenes." $\underline{22}$

By forging a connection between Jesus and the Essenes, Graetz was using scholarly tools that had been available for generations. Graetz's analysis of how the mysticism of the Essenes evolved also relied on the insights made by other scholars. The scholarl y consensus of Graetz's day held that Essene mysticism originated in Egypt and India. Even George Eliot's visitor echoed that sentiment: "He moreover traces Essenism back to Egypt and thence to India, the cradle of all religions, etc., etc., with much mor e which he uttered with an unction rather amusing in a soirée tête-à-tête." $\underline{23}$ Specifically, the Essenes were thought of as the transmitters of oriental habits of allegory and speculation. Ritschl, for example, wrote at length about the connection between Alexandria and the mystical impulses of the Essenes before Graetz published h is own work. ${ }^{24}$ Although Salvador had rejected the idea that Jesus acquired his magical skills from a sojourn in Egypt, he did assert that an oriental habit of mystical and allegorical speculation originating in Alexandria--and articulated by Philo--had penetrated Jewis h society, partially through Essene circles. $\underline{25}$

Whether or not Graetz consciously incorporated Ritschl or Salvador's specific work on mysticism, it would have been natural for him to understand unappealing and particularly mystical elements of Judaism as coming from oriental influences. ${ }^{26}$ The sense of mysticism as a Hellenistic cultural expression was a commonly held belief in the scholarly tradition of the nineteenth century. ${ }^{27}$ Graetz may also have been relying on the larger assumption that Jews were exposed to mystical thinking during their exile in Babylon. $\stackrel{28}{2}$ Oriental [End Page 139] allegory, the motor force behind mysticism, represented for Graetz the dark side of rabbinic exegesis as expressed in excessive and misdirected interpretations of Scripture. The ascetic life of the Essenes, who thought in terms of a "Schwärmerische u nd Mystische gerichtete Phantasie" provided fertile ground for this mystical impulse. ${ }^{29}$ Graetz's 
conclusion was that "if we can assume the information about the Essenes in Josephus and Philo to be historical--an assumption by no means certain--then they may actually have been the first to attempt to explain the Bible and the commandments ph ilosophically, that is, allegorically." $\underline{30}$

Why was Graetz intent upon drawing this portrait of the Essenes as proto-Christians and carriers of oriental allegory and mysticism? One reason depends upon Judaism's perceived position in German Protestant culture. Graetz and other intellectuals of the <

I $>$ Wissenschaft movement had to confront a dominant culture that thought of rabbinic Judaism as a relic without its religious meaning. $\frac{31}{}$ What better way to combat this than to show that Christianity was in fact dependent upon Judaism for its existence and its ideas? In other words, if Christianity evolved out of Essenism then in a fundamental way Judaism-not Christianity--was the truly c reative and evolutionary force in history.

Graetz was not the first Jewish scholar to respond in this way. Abraham Geiger, the leader of the more radical Reform movement, which was in competition with Graetz's own more historically-minded reform efforts, presented Jesus as a Pharisee. According to Geiger, Jesus

was a Jew, a Pharisean Jew with Galilean coloring--a man who joined in the hopes of his time and who believed that those hopes were fulfilled in him. He did not utter a new thought, nor did he break down the[End Page 140] barriers of nationality.... He did not abolish any part of Judaism; he was a Pharisee who walked in the way of Hillel. $\underline{32}$

This satisfied Geiger's own desire to make Christianity evolve out of Judaism. More directly it responded to the same Protestant critique that alleged Pharisaism to be a stagnant legalistic movement. In Geiger's view the fact that Jesus was a Pharisee pro ved that Pharisaism was an evolving tradition that had a well-spring of religious meaning. Not only did this counter Christian claims, it helped Geiger claim these "progressive" Pharisees as the ancient precedent for his own Reform movement. $\underline{\underline{33}}$

Graetz chose to emphasize the Essene origins of Christianity in the face of Geiger's pharisaic model. Besides Graetz's fierce antipathy to Geiger because of personal and religious rivalry, Graetz feared that characterizing Christianity as an outgrowth of pharisaic Judaism, as Geiger seemed to be doing, risked contaminating rabbinic Judaism with the corruptions of a mystical proto-Christianity. By making Jesus an Essene, Graetz marginalized nascent Christianity from the mainstream Pharisees--the Jews who $r$ epresented for Graetz an ancient model of his own vision of a progressive but historically aware conservative Judaism. $\underline{34}$

Why then did Graetz follow the evolution of mysticism beyond the Essenes? At least one solution will present itself once we see how Graetz shaped the narrative of Jewish mysticism. By the time Graetz began to write, the study of Kabbala itself was beginni ng to flourish. One of the first substantive works was Adolphe Franck's La Kabbale ou la philosophie religieuse des Hebreux (1843) with a German translation by Adolph Jellinek in 1844. Franck presented the Zohar, the pre-eminent mystical tex t, and other kabbalistic 
ideas as an ancient body of doctrine that predated the Alexandrian philosophers. The Kabbala's original sources were to be found in the Chaldean and Persian thought of Zoroastrianism. [End Page 141] Still, according to Franck, Kabbala remained an elemental and even positive part of Judaism, a point rejected by Jellinek, who felt that the Kabbala, or at least the foundational text of the Zohar, was a foreign accretion to contemporary, postTalm udic Judaism. $\underline{35}$

Using the Essenes as the focal point of transmission, Graetz identified a continuous lineage from the Alexandrian allegorists to the medieval kabbalists. $\frac{36}{6}$ The Essenes had discovered the secret allegorical torah that was the origin of the Kabbala. ${ }^{37}$ A later group of kabbalists would be described as "dieser Allegoristen-Schule." ${ }^{38}$ While he disagreed with Franck on the early date of the Zohar, Graetz still thought the Zohar was the ultimate literary incarnation of this impulse to uncontrolled allegory and aggadah (the literary embellishment of biblical stories). ${ }^{39}$ Uncontrolled allegorical aggadah could lead to doctrines that sounded dangerously like Christian dogma; Graetz thought one could hear in it echoes of the Trinity. ${ }^{40}$ It was clear, for example, that aggadah dominated the language of early Christianity. In the parables of Jesus and in the language of Paul it was easy to see the effects of this kind of allegorical language. ${ }^{41}$ The Kabbala merely preserved and expanded upon this style of mystical thinking.

The growth of allegorical kabbala was not peripheral to normative Judaism. Graetz felt that the Kabbala was waging a "Krieg auf Tod und Leben" against non-mystical (perhaps nonallegorical) rabbinic Judaism. ${ }^{42}$ One result of this unrelenting attack was that the Kabbala provoked the creation of sects within Judaism, a phenomenon that for Graetz also harkened back to the Essenes, whom he had distinguished from the merely political parties of the Pharisees and Sad ducees. $\stackrel{43}{ }$ The medieval Lurianic Kabbala created "eine neue jüdische Sekte" with practices that directly echoed Essene rituals, including wearing a white robe on the Sabbath. $\underline{44}$

Throughout Graetz's discussion, we can see that he thought the Kabbala provoked among medieval and later Jews the same kind of messianic delusions [End Page 142] that had circulated among the Essenes and which found fullest expression in the growth of Christianity. ${ }^{45}$ Mysticism and "messianische Schwärmerei" fed off each other. ${ }^{46}$ This tendency drew the Jews to embrace Christian-like doctrines or to be seduced by Christianity itself. ${ }^{47}$ Messianic delusions insinuated themselves into Jewish thought and society throughout the Middle Ages. ${ }^{48}$ The same messianic excesses manifested themselves in the outpouring of support for the seventeenth-century false messiah Sabbatai Zevi. This, too, was the result of uncontrolled mystical thinking. ${ }^{49}$ In order to illustrate how mystical "enthusiasm" for a charismatic leader could grow into a messianic movement, Graetz used the experience of Sabbatai Zevi to suggest that the same process occurred in the circles surrounding Jesus. Seen in the context of messianic Sabbatianism, Christianity was just another excess of mysticism. At the same time the comparison between Jesus and Sabbatai Zevi pointed up the Christian-like delusion of mystical Sabbatianism. ${ }^{50}$ Significantly, Graetz treated Spinoza in the same section of his history as Sabbatai Zevi. The danger of such allegorical thinking, in Graetz's mind, had also led Spinoza astray into atheism. $\underline{51}$ 
Contemporary Hasidism represented for Graetz the ultimate manifestation of that long tradition of mysticism and its accompanying corruption of religion. He saw the Kabbala as living on in the corrupt pietistic circles of Poland and Russia. Graetz drew on a long tradition of animus to the Kabbala. This attitude was a legacy of the haskala, the movement of the enlightenment of European Jewry in the eighteenth century. Its proponents looked upon Hasidism [End Page 143] with scorn. ${ }^{52}$ For example, Solomon Maimon's poignant autobiography, recounting his flight from the cloistered world of East European Jewry, had already provided a language in which to attack the mystical-allegorical nature of Kabbala, and thus by implication Hasidism:

Originally, the Kabbalah was nothing but psychology, physics, morals, politics and such sciences represented by means of symbols and hieroglyphics in fables and allegories, the occult meaning of which was disclosed only to those who were competent to unde rstand it. By and by, however, perhaps as the result of many revolutions, this occult meaning was lost, and the signs were taken for the things signified. $\underline{53}$

Other great figures of the haskala shared this sentiment. Moses Mendelssohn also thought that the Kabbala was a suspiciously "oriental system" of metaphors. $\stackrel{54}{\text { Graetz echoed some }}$ of the sentiments of Nachman Krochmal, the great Jewish philosopher, who recognized the potential for allegorical thinking to decay into outlandish expressions of mysticism like Sabbatianism. ${ }^{55}$ As with so many other parts of his historical synthesis, Graetz focused a rather diffuse tradition into a powerful equation and made it accessible to a wider audience, including later historians like Simon Dubnow.

In concentrating this argument against Hasidism, Graetz went further and joined contemporary mysticism to its medieval and ancient antecedents. He would write that mysticism "took on new life through Isaac Luria and his disciples and to this day dominates the circles of the Hasidim." ${ }^{56}$ Graetz was particularly concerned that the mysticism of Hasidism would lead to further messianic crises:

Such were the aberrations produced by the messianic belief. And we have no guarantee that in our day in the bosom of the modern adherents [End Page 144] of the Zohar, among the Hasidim in Poland, Galicia, Hungary..., whose propaganda becomes increasingly more intensive, a false messiah will not burst forth some fine morning and sow new confusion. There would be no shortage of mindless, believing masses, $\mathrm{n}$ ot even of standard-bearers for any hasidic rebi $[\mathrm{sic}]$ who could bring them to believe in him and occasionally perform a miracle. $\underline{57}$

By his emphasis on the messianic corruptions of Hasidism, Graetz implicitly connected the contemporary movement with its historic predecessors, particularly the Essenes. He explicitly joins the two movements by asserting that Hasidism itself is the reinca rnation of Essenism. In fact it is a "new Essenism" in which the old practices have survived or been resurrected: "There is emerging in Poland a new Essenism, with forms similar to the old one, with washing and bathing, with white clothes, miracles, and p rophetic dreams." $\underline{58}$ This was an old battle being fought anew. The Pharisees used to mock an Essene as a "foolish Chasid." $\underline{59}$ Indeed, the lifestyle of the Essenes was one of "Chasidut." $\underline{60}$ The 
Essenes could trace their roots back to the Assidäer of the time of Maccabees or the pious (hasidim) of the Talmud. The Hebrew hasid could thus suggest contemporary European mystics as much as ancient pietists. $\frac{61}{}$ Contemporary Hasidism had merely brought this ancient Essenism back to life. $\underline{62}$

The metaphor of the Essenes allowed Graetz to link the various kinds of Jewish mysticism together. To what end? Why did Graetz present Jewish history in this way--as a constant struggle of normative Judaism to shake itself free of the recurring corruption s of mysticism? Like other Wissenschaft scholars, he wanted to present Judaism as a rational progressive religion that had long ago left behind any oriental trappings that could offend German sensibilities. $\frac{63}{}$ In that case why not dismiss mysticism out of hand or at the most give it cursory treatment and concentrate on the progressive monotheism of rabbinic Judaism?

I can only offer a tentative answer to this question. If Graetz could show that there was a continuous lineage of mysticism that ran as an undercurrent throughout Jewish history, it would be easier to see mysticism itself as running parallel to rabbinic J udaism and not as an offshoot of it. Just as Christianity was marginalized by being associated with the Essenes, so too would other [End Page 145] forms of Jewish mysticism be isolated from rabbinic Judaism. In other words each incarnation of mysticism had more in common with its predecessor than with contemporary rabbinic Judaism. (Nor should we discount the possibility that Graetz's inclusive visi on of Judaism led him to describe all aspects of Jewish life no matter how distasteful they were to him.)

Graetz may have found a precedent for his treatment of mysticism in the way some Christians attacked rabbinic Judaism itself as a corrupt tradition of allegorical interpretation. Before looking specifically at Graetz's response to the Protestant critique of rabbinic allegory, it is important to see that Graetz was used to internalizing "Christian" historical categories. Even Graetz's sense of Judaism was colored by Christian language. Graetz wrote of rabbinic Judaism as being in some way a creation of Chr istianity. The opposition of Christianity to the legal nature of Judaism pushed the Jews even further into a legalistic mode of thinking. The Talmud was the result of that interaction. ${ }^{64}$ Graetz was also quite willing to accept that there was something particularly captivating about Jesus that created a religious enthusiasm among his followers. ${ }^{65}$ Indeed, Graetz could not abandon the Christian idea of a dichotomy between law and spirit. His positive assessment of Jesus and his influence on Judaism was predicated on this dichotomy. ${ }^{66}$ Indeed, Christian categories provided Graetz with a stock of metaphors which he used to analyze developments in Jewish history. "Judaism," he wrote, "began as a negation, a negation of paganism; it appeared on the stage of history as a kind of Protestant ism." $\underline{67}$

More importantly, Christian ideology gave Graetz a way to understand Judaism's survival in history, or at least to represent Jewish history to an audience familiar with Christian concepts. Graetz presented the whole drama of Jewish survival as a miracle c omparable to the miracles of Christian tradition. $\frac{68}{2}$ The centuries of Jewish suffering and survival as a people in the face of that suffering became the true "miracle" of Jewish history. ${ }^{69}$ As Graetz 
wrote to a fictional Jewish correspondent:

I have already explained to you once that a religion which should attract adherents must rely on miracles and can survive only if the miracles [End Page 146] continue. Which religion can show more conspicuous, striking miracles than Judaism? It does not have to squeeze them out of obscure texts or exhibit them in shrines laden with miraculous relics for they are visible in the flesh wherever Jews wander. You a nd I are likewise parts of this miracle. $\underline{70}$

The miracle was ongoing as the Jewish people was constantly being renewed: "The Jewish people is heading before our very eyes toward a process of rejuvenation which previously was scarcely imagined." $\underline{71}$ The Wunderof Jewish history's renewal not only happened in ancient days but also in Graetz's own "wunderlosen ... Epoche." $\underline{72}$ The miracle of Jewish survival could easily compete with the putative miracles of Christianity.

Graetz's internalization of Christian historical models was particularly intense, and the discussion above is meant to show that Graetz was used to thinking about Jewish history in

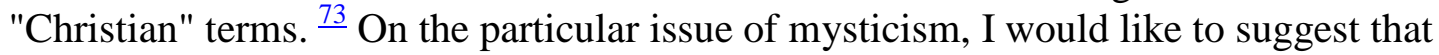
Graetz transmuted a generalized Christian antagonism towards the rabbinic tradition and focused it on the Kabbala. Anti-rabbinic sentiments could be found in many places in the Christian historical tradition. Still, it is tempting to speculate--and it must remain a speculation--that Graetz had a particular inspiration for his attitude, or at least a precedent through which he could focus his larger polemical concerns.

Graetz's interest in Jacques Basnage's eighteenth-century Histoire des Juifs should draw our attention to the impact of his work on Graetz. The critique of rabbinic allegorical thinking found in Basnage's work is reminiscent of Graetz's own critiqu e of allegorical mysticism. ${ }^{74}$ In his sweeping history of the Jews Basnage articulated a detailed critique of rabbinic thought. The rabbins drew on a tradition of oriental allegory; they created rituals and laws from an allegorical reading of Scripture. For Basnage the mysticis $m$ of the rabbins was the result of their allegorical thinking. This corrupted reading of Scripture was an [End Page 147] ever-present characteristic of rabbinic Judaism. It began in Alexandria and followed contemporary "Talmudic" Jews to Poland and Russia. Indeed, mysticism had led to the atheism of Spinoza. $\underline{75}$

Graetz might have found in Basnage a way to systematize his own thinking about mysticism. Of course, he could not accept Basnage's indictment of the larger rabbinic tradition. However, he did not reject Basnage's more general synthesis of the history of a llegory and its deleterious effects on religion. Instead, Graetz isolated the critique of allegory and focused it solely on Jewish proponents of mysticism. He turned this critique of allegory against the ancient and contemporary adherents of the Kabbala-- the Essenes and the mystical pietists of Eastern Europe. In doing so, he disentangled mysticism from rabbinic Judaism. Rabbinic interpretation of the Bible was a legitimate expression of Judaism. Mysticism was a distinct aberration.

Ironically, even though he denigrated mysticism, Graetz's reading of the history of Jewish 
mysticism facilitated its renaissance in the work of the great twentieth-century scholar of Kabbala, Gershom Scholem. Graetz bequeathed to Scholem a picture of an a ncient Jewish mysticism that had survived from the Essenes to Hasidism. Graetz may have been wrong to link the Essenes and contemporary Hasidism, wrenching each incarnation of mysticism out of its historical context. Still, Scholem could see in Graetz's n arrative a continuous lineage of mystical thinking. ${ }^{76}$ That understanding of mysticism survived as Scholem invested Kabbala with a positive vitality crucial to the evolution of Judaism. The capaciousness of Graetz's view of Judaism and his intent to preserve it from Christian attack thus prepared the way for Scholem to explore mysticism as a positive aspect of Jewish history. Although these two scholars disagreed about the meaning of mysticism, their sense of its larger role in the narrative of Jewish history had remarkable affinities. Perhaps it is true, as one historian recently wrote, "private perspectives can be, in the right hands, a pathway to historical knowledge ... passion, even prejudice, may provide access to insights closed to cooler, more distant researchers." $\underline{77}$ In a way, this is true of both Graetz and Scholem.

Trinity College, Hartford, Connecticut

\section{Notes}

I presented early versions of this paper at the Hebrew University in Jerusalem and at the Center for Judaic Studies at the University of Pennsylvania in 1994. I would like to thank Daniel Schwartz, Michael Heyd, Isaiah Gafni, Derek Penslar, Nancy Sinkoff, and Iddo Landau in Jerusalem and at the Center, Anthony Grafton, Ross Kraemer, Robert Liberles, and Elliot Horowitz.

1. For recent work on Graetz see Michael A. Meyer, "The Emergence of Jewish Historiography: Motives and Motifs," Essays in Jewish Historiography, ed. Ada RapoportAlbert (Middletown, Conn., 1988), this article also published in History and Theory Beiheft 27 (1988), 173-75; Ismar Schorsch, From Text to Context: The Turn to History in Modern Judaism (Hanover, N.H., 1994), passim.; and Jay Harris, How Do We Know This? Midrash and the Fragmentation of Modern Judaism (Albany, 1995), 17 5-210.

2. See David Biale, Gershom Scholem: Kabbalah and Counter-History (Cambridge, Mass., 1979), 22-24, who argues that Graetz understood Jewish mysticism to be the product of a specific response to philosophical speculation of the Middle Ages. Graetz may have believed this in terms of specific kabbalistic doctrines, but in the larger sense of mysticism as a style of thinking derived from allegory, Graetz saw Jewish mysticism as an ancient and ongoing aspect of Judaism.

3. Eusebius relied on Philo's description of the therapeutae in De vita contempletiva. See Eusebius, Ecclesiastical History, tr. K. Lake (2 vols.; Cambridge, Mass., 1980), I, 145-57 [II, 16-17].

4. Josephus, Jewish War, tr. H. St. J. Thackeray (2 vols.; Cambridge, Mass., 1976), I, 36987 [II, 118-62]. 
5. Jean Riaud, "Les Thérapeutes d'Alexandrie dans la tradition et dans la recherche critique jusqu'aux découvertes de Qumrân," Aufstieg und Niedergang des Römisches Welt, XX/II (1987), 1195-1295. See S. Wagner, Die Essener in der wissenschaftlichen Diskussion, vom Ausgang des 18. bis zum Beginn des 20. Jahrhunderts [Beihefte zur Zeitschrift für die alttestamentliche Wissenschaft] (Berlin, 1960). Azzariah de 'Rossi, the author of the Me'or Enayim (1573 ) acknowledged the apparent similarities between the Essenes and Christian monks but emphasized that the Essenes were still Jewish sectarians who had only influenced Christian monasticism. See Joanna Weinberg, "The Quest for Philo in SixteenthCentury Jew ish Historiography," Jewish History: Essays in Honour of Chimen Abramsky, eds. Ada Rapoport-Albert and Steven J. Zipperstein (London, 1988), 168-69.

6. Samuel Sandmel, "Parallelomania," Journal of Biblical Literature, 81 (1962), 7, notes Graetz's identification of Jesus as an Essene. Jacob Fleischman, The Problem of Christianity in Jewish Thought from Mendelssohn to Rosenzweig (in Hebrew) (Jerusalem, 1964), does not include Graetz. The outlines of the problem, with special regard to Abraham Geiger, have recently been studied by Susannah Heschel inAbraham Geiger on the Origins of Christianity (Ph.D. diss., U. Pennsylvania, 198 9).

7. Graetz, Geschichte der Juden (11 vols.; Leipzig, 18702), III, 277: "Von den Essäern ging auch in dieser Zeit der erste Ruf aus, der Messias müsse in kurzer Zeit erscheinen, 'das Himmelreich ist nahe."' This later edition (1870) contains $m$ aterial on Christianity not found in the edition of this volume published in 1856. I will cite from volume III of the 1870 edition unless otherwise indicated.

8. Geschichte, III, 273.

9. Ibid., 277 .

10. Ibid., 278-79. "Seine Lebensweise war in der That ganz nach essäischem Zuschnitte." And: "Johannes mochte wohl mit andern Essäern in der Wüste, in der Nähe des todten Meeres...." Graetz's appellation of John is on p. 285.

11. Ibid., 282.

12. Ibid., 282; III, 100 (on the Essenes and magic).

13. Ibid., 292. "Jesus lehrte vor Allem seinen mänlichen und weiblichen Jüngern die essäisch leidenden Tugenden der Selbstverleugnung, der Demuth, der Güterverachtung, der Berträglichkeit und Friedfertigkeit."

14. Graetz, Sinaï et Gologotha ou Les Origines du Judaïsme et de Christianisme, tr. Moses Hess (Paris, 1867), 409.

15. Geschichte, III, 285. 
16. Ibid., 312.

17. Ibid., 312.

18. The first post-medieval scholar to make the connection between the Essenes and Christianity was J. G. Wachter, De Primordiis Christianae religionis libri duo, quorum prior agit de Essaeis Christianorum inchoatoribus, alter de Christianis, Essaeorum pos teris, in an unpublished manuscript from 1713, cited in Heschel, Geiger, 255.

19. Joseph Salvador, Jésus-Christ et sa doctrine (2 vols.; Paris, 1838), I, 119, on whom see Michael Graetz, The Jews in Nineteenth-Century France: From the French Revolution to the Alliance Israélite Universelle, tr. Jane Marie To dd (Paris, 1989), passim; and Jay R. Berkovitz, The Shaping of Jewish Identity in Nineteenth-Century France (Detroit, 1989), 128-49.

20. See Wagner, Essener, passim; and Heschel, Geiger, 334-42; and idem, "The Image of Judaism in Nineteenth-Century Christian New Testament Scholarship in Germany," JewishChristian Encounters over the Centuries: Symbiosis, Prej udice, Holocaust, Dialogue, ed. Marvin Perry and Frederick M. Schweitzer (New York, 1994), 215-41.

21. For a discussion of Crucifixion, see Edgar K. Goodspeed, Modern Apocrypha (Boston, 1956), 20-28. On the afterlife of Venturini, see G. O'Collins and D. Kendall, "On Reissuing Venturini," Gregorianum, 75 (1994), 241-65.

22. Selections from George Eliot's Letters, ed. Gordon S. Haight (New Haven, Conn., 1985), 88.

23. Haight, Letters, 88.

24. Wagner, Essener, 111, citing Albrecht Ritschl, "Ueber die Essener," Theologische Jahrbücher, 14 (1855), 315-56.

25. Salvador, Jésus-Christ, I, 126. On the magic training of the Essenes, see 204-7 and on allegory, 482-83.

26. On perceptions of Judaism as exotic, see Paul Mendes-Flohr, Divided Passions: Jewish Intellectuals and the Experience of Modernity (Detroit, 1991), 77-132.

27. See Riaud, Thérapeutes, 1256-57, referring, for example, to A. Gfrörer, Philo und die Alexandrische Theosophie (Stuttgart, 1831).

28. An idea found in Georg Friedrich Creuzer, Symbolik und Mythologie der alten Völker, besonders der Griechen (Leipzig, 1810). See I. Lévy, Recherches esséniennes et pythagoriciennes (Paris, 1965), 57-58 on Creuzer who, "rec onnaissant nombre de traits de parenté entre Esséniens et Pythagoriciens, crut pouvoir concilier Philon et Josèphe en imaginant que les uns et les autres étaient tributaires, en dernière analyse, d'une part, des doctrine s 
révélées aux Juifs à l'époque de l'exil de Babylone..." (cited in Riaud, Thérapeutes, 125657).

29. Geschichte (1856), III, 100: "Es lag wohl nicht von vorn herein in der Absicht der Essäer, sich in eine Art kabbalistischer Mystik zu vertriefen, aber ihr asketisches Wesen, ihr Stilleben, welches der Beschaulichkeit so viel Nahrung giebt, ihr e Sorgenlosigkeit für die Familie, endlich ihre religiöse Schwärmerei mußten sie darauf fürhen, andere Wahrheiten in Judenthum zu suchen, als nüchternen Sinn darin erscheint."

30. Graetz, Structure of Jewish History and Other Essays, tr. and ed. Ismar Schorsch (New York, 1975), 103.

31. See Uriel Tal, Christians and Jews in Germany: Religion, Politics, and Ideology in the Second Reich, 1870-1914, tr. N. Jacobs (Ithaca, 1975); Hans Liebeschütz, Das Judentum im deutschen Geschichtsbild von Hegel bis Max Weber (Tübin gen, 1967); Nathan Rotenstreich, Jews and German Philosophy: The Politics of Emancipation (New York, 1984); Jay Harris, Nachman Krochmal: Guiding the Perplexed of the Modern Age (New York, 1991); C. Hoffman, Juden und Judentum in Werk deu tschen Althistoriker des 19. und 20. Jahrhundert (Leiden, 1988); and Amy Newman, "The Death of Judaism in German Protestant Thought from Luther to Hegel," in Journal of the American Academy of Religion, 61 (1993), 455-84.

32. Geiger, Judaism and Its History, tr. M. Mayer (2 vols.; New York, 1866), I, 215.

33. The claims and counterclaims of the Wissenschaft scholars for historical precedents often became quite involved. See, e.g., Daniel R. Schwartz, "Pharisees and Kingdom of Priests" in his volume of collected essays, Studies in the Jewish Backgroun d of Christianity (Tübingen, 1992), 77, n. 79: "Indeed as early as 1842 Geiger was forced to defend himself against the claim that he was a Sadducee or Karaite; he counterattacked by branding the Orthodox 'rabbinic Karaites' enslaved to the lette $r$ of the Talmud and the halachic literature." For another instance of the intra-Jewish use of Sadducee, see Michael K. Silber, "The Emergence of Ultra-Orthodoxy: The Invention of a Tradition," The Uses of Tradition, ed. Jack Wertheimer (New York, 1 992), 66-69.

34. Heschel, Geiger, 181: "Presenting Jesus as an Essene would keep him within the context of Jewish history, but would consign him to the fringes of that history." See, too, Gösta Lindeskog, "Jesus als religionsgeschichtliches und religioses Prob lem in der modernen jüdischen Theologie," Judaica, 6 (1950), 190-229, 241-68, esp. at 222: "... daß die Juden oft in Jesus einer Essäer sehen wollen, den die Essäer waren Häretiker im Verhältnis zu dem rechtgläub igen Judentum, und damit hat man also einen Erklärungsgrund zu dem Unjüdischen bei Jesus gefunden."

35. On Franck, see Moshe Idel, Kabbalah: New Perspectives (New Haven, 1988), 8-9; and Perrine Simon-Nahum, La cité investie. La "Science du Judaïsme" français et la République (Paris, 1991), 144-47. The French scholar S olomon Munk saw the roots of the Kabbala in Alexandrian philosophy; see Simon-Nahum, Cité, 147, referring to 
Munk, Mélanges de Philosophie Juive et Arabe (Paris, 1859).

36. Graetz, Geschichte (1863), VII, 254: "Wie ihre Vorläufer, die alexandrinischen Allegoristen aus falscher Zweckdeutung der Religionsvorschriften sich über die Riten des Judenthums hinwegsetzen, ebenso verfuhr mancher consequente Aufgekl\&au ml;rte in dieser Zeit."

37. Geschichte (1856), III, 101.

38. Geschichte (1863), VII, 254.

39. Ibid., 249-50. See note 12, "Autorschaft des Sohar," at 488.

40. Ibid., 249: "Enthält der Sohar doch sogar Aeußerungen, welche dem christlichen Dogma von der Dreienigkeit der Gottheit günstig klingen!"

41. Geschichte (1856), III, 340.

42. Geschichte (1882), X, 422.

43. Geschichte (1856), III, 105.

44. Geschichte (1866), IX, 447.

45. Ibid., 241: "Wie bei den Essäern, so war auch bei den soharistischen Mystikern die Messiashoffnung der Angelpunkt ihrer ganzen Lehre."

46. Geschichte (1863), VII, 226: "Die Mystik war von jeher der Boden, auf dem messianische Schwärmereien gediehen."

47. Geschichte (1866) IX, 93: "Die Kindische Auslegung der Namen und Buchstaben in der heiligen Schrift von Seiten der Kabbalisten war es, die Capnio anstaunte, und er wendete sie auf die Dogmen des Christenthums an." And see Geschichte (1863) VII, 229 for the story of the Jewish community's seduction into a quasi-Christianity by the pseudo-prophet of Avila (c. 1295). On Luria's Christian-like doctrines, see VII, 225: "In diesem Sinne lehrte er seine Kabbala--im Gegensatz zur oberflä chlichen und niedern, die sich mit dem Sefirot abquält und, wie er spöttelte, eine Art Zehneinigkeit, statt der christlichen Dreienigkeit, aufstellt."

48. Graetz, Structure, 166-67.

49. Ibid., 105-6.

50. Graetz, Sinaï, 376-77. See the attempts to exploit Sabbatianism as a way of legitimating Jesus as the Messiah in W. D. Davies, "From Schweitzer to Scholem: Reflections on 
Sabbatai Svi," Journal of Biblical Literature, 95 (1976), 529-58.

51. Geschichte (1882), X, 171. Geiger, too, thought that Spinoza was influenced by the Kabbala. See Geiger, Judaism, 294: "He [Spinoza] likewise contended against the Kabbalah, and yet had received many an impulse from its doctrines; he changed its doctrine of Emanation into that of Immanation." On Spinoza as a kabbalist, see Richard H. Popkin, "Spinoza, Neoplatonic Kabbalist?" Neoplatonism and Jewish Thought, ed. Lenn E. Goodman, (Albany, 1992), 387-411.

52. See Raphael Mahler, Hasidism and the Jewish Enlightenment: Their Confrontation in Galicia and Poland in the First Half of the Nineteenth Century, tr. (from Yiddish) E. Orenstein, and tr. (from Hebrew) A. Klein and J. M. Klein (Philadelphia, 1985); and Joseph Perl, Über das Wesen der Sekte Chasidismus (Jerusalem, repr. 1977). Note the comment of Idel, Perspectives, 10: "It may indeed be that later negative attitudes of Heinrich Graetz, Moritz Stein-schneider, and Solomon Rubin tow ard Kabbalah were based upon their reaction toward Eastern European Hasidism."

53. Maimon, An Autobiography, tr. Y. Clark Murray (London, 1888), 94-95, cited in Moshe Idel, "Perceptions of the Kabbalah in the Eighteenth Century," in Journal of Jewish Thought and Philosophy, 1 (1991), 62.

54. Idel, "Kabbalah," 66.

55. See David Biale, "The Kabbala in Nachman Krochmal's Philosophy of History," in Journal of Jewish Studies, 32 (1981), 85-98, esp. 89. Heinrich Heine also feared the effects of a degenerative allegory (see Harris, Krochmal, 307, note 39).

56. Graetz, Structure, 106.

57. Ibid., 169.

58. Geschichte (1870), XI, 102. "Es entstand in Polen ein neues Essäerthum, mit gleichen Formen wie das alte, mit Waschungen und Baden, mit weißen Kleidern, Wunderheilungen, prophetischen Träumereien."

59. Geschichte, III, 103.

60. Ibid., 102.

61. Ibid., 522.

62. Geschichte (1870), XI, 112.

63. Biale, Scholem, 6.

64. Geschichte (Magdeburg, 1860), V, 198: "Der Talmud war das Produkt dieser gegen- 
sätzlichen Bewegung; er war die allein herrschende Autorität innerhald des Judenthums geworden und hatte die Bible aus dem Volksbewutzstein verdrängt."

65. Graetz, Sinaï, 376-77.

66. Ibid., 320.

67. Graetz, "The Construction of Jewish History," Ideas of Jewish History, ed. Michael Mayer (Detroit, 1987), 222.

68. Graetz, Structure, 203.

69. A point also seen by Francis Schmidt in La pensée du Temple: De Jérusalem à Qumrân (Paris, 1994), 49. Heschel has noted an analogous effort by Geiger--in his response to the biographies of Jesus by Strauss and Renan--in w hich the Jewish people takes on the religious consciousness ascribed to Jesus. Heschel, Geiger, 213-14.

70. Graetz, Structure, 248.

71. Ibid., 143.

72. Geschichte (1870), XI, 2.

73. Graetz was not the first Jewish thinker to absorb Christian historical structures. Amos Funkenstein has noted that Rashi, the great medieval Jewish explicator of the Bible, assimilated the image of the suffering servant to his own understanding of Israel' s history. In Rashi's mind, "the suffering servant refers not to an individual but rather to all of Israel which, through its suffering and humiliation in dispersion, atones vicariously for the sins of all nations.... In other words, by polemicizing again st Christian theology--against the identification of Christ with the 'suffering servant'--Rashi absorbed one its cardinal tenets-namely the dogma of vicarious suffering as a means of salvation; Israel takes here the role of Christ." Amos Funkenstein, "Th e Dialectics of Assimilation," Jewish Social Studies, 1 (1995), 9.

74. On Graetz's generally critical opinion of Basnage, see Geschichte (1882), X, 315-18. On Basnage, see Jonathan M. Elukin, "Jacques Basnage and the History of the Jews: Polemic and Allegory in the Republic of Letters," JHI, 53 (1992), 6 03-31.

75. Elukin, "Basnage," 613-14.

76. Scholem, for example, argued that there was an early form of a mystical Jewish Gnosticism that preceded the Christian heresy. In this he disagreed with Graetz on the nature of Gnosticism (Graetz saw it as distinctly non-Jewish philosophy) but agreed with him on the larger issue of the ancient roots of Jewish mysticism. See Biale, Scholem, 131, and Guy Gedaliahu Stroumsa, "Gnosis and Judaism in Nineteenth Century Christian Thought," Journal of Jewish Thought and Philosophy, 2 (1992), 45-62. G raetz's devision 
between rabbinic interpretation and mysticism may also have shaped Scholem's own understanding of the separation between Rabbinism and Kabbala. See Idel, "Rabbinism Versus Kabbalism: On G. Sholem's Phenomenology of Judaism," Modern Jud aism, 11 (1991), 281-96. I owe this reference to Ronald Kiener.

77. Peter Gay, cited in Linda Colley, Namier (London, 1989), 43. 